\title{
Tribological performance and corrosion behavior of CoCrMo alloy
}

\author{
Hadda Rezzag \\ Laboratory of Metallurgy \& Materials engineering (LMGM), University Badji Mokbtar, B. P. 12, Annaba 23000, Algeria. \\ Research Center in Industrial Technologies CRTI, P. O. Box 64, Cheraga 16014 Algiers, Algeria \\ rezzagbiom@gmail.com
}

Latifa Kahloul, Hacène Chadli

Laboratory of Mines, Metallurgy, and Materials (L3M), National School of Mines and Metallurgy.Annaba, 23000, Algeria. latifabiomat@gmail.com, chadli_hacene@yahoo.fr

\author{
Alima Mebrek \\ Research Center in Industrial Technologies CRTI, P. O. Box 64, Cheraga 16014 Algiers, Algeria \\ a.mebrek@crti.dz.
}

\section{Adel Saoudi}

Centre de Recherche Scientifique et Technique en Analyses Physico-Chimiques CRAPC, Zone Industrielle Bou-Ismail, Tipaza, PO 384, RP 42001, Algeria

saoudi_dl@yahoo.com

\begin{abstract}
The present work focuses on the Tribological properties and corrosion behavior evaluation of sintered CoCrMo alloy. The CoCrMo alloy was elaborated by Powder metallurgy process at various sintering temperatures $\left(1200^{\circ} \mathrm{C}, 1250^{\circ} \mathrm{C}\right.$ and $\left.1300^{\circ} \mathrm{C}\right)$. The structural properties were characterized by $\mathrm{X}$-ray diffraction and scanning electron microscopy. The tribological characteristics were measured using a dry disc-ball tribometer. The corrosion behavior of the samples was studied using different electrochemical tests in a simulated physiological environment (Hank's solution). The obtained results show that higher sintering temperatures have a positive impact on the tribological behavior as well as the corrosion resistance of CoCrMo alloys. The sintered samples at $1300^{\circ} \mathrm{C}$ showed a better resistance to friction wear and a lower corrosion rate.
\end{abstract}

KEYWORDS. CoCrMo alloy; Powder metallurgy; Wear; Electrochemical properties.

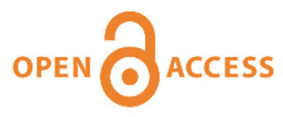

Citation: Rezzag, H., Kahloul, L., Chadli, H., Mebrek. A., Saoudi, A. Tribological Performance and Corrosion Behavior of CoCrMo Alloy, Frattura ed Integrità Strutturale, 59 (2022) 129-140.

Received: 14.07.2021 Accepted: 14.10 .2021 Published: 01.01.2022

Copyright: (C) 2022 This is an open access article under the terms of the CC-BY 4.0, which permits unrestricted use, distribution, and reproduction in any medium, provided the original author and source are credited. 


\section{INTRODUCTION}

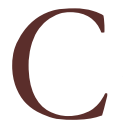

obalt-based alloys are widely used in the biomedical field. The cobalt-chromium- molybdenum alloy (CoCrMo) is mainly used for orthopedic implants and dental devices [1]. They represent the preferred choice for artificial joints and metal-to-metal contact [2] because of their excellent properties in terms of wear and corrosion resistance aligned with a good biocompatibility with the human tissues [3]. The high biocompatibility of these alloys is related to the immediate formation of a protective passive film on the surface. This film is mainly composed of chromium oxide $\mathrm{Cr}_{2} \mathrm{O}_{3}[4]$, with a small contribution of $\mathrm{Co}$ and Mo oxides [5].

Several techniques were used for the development of Co-based alloys such as casting and forging [6]. However, these techniques present the disadvantages of solidification defects and precipitation [7] including a coarse microstructure, low resistance and elongation. Hence, it was a great interest to improve the mechanical reliability of these CoCrMo alloys in order to achieve high durability of medical implants.

Powder metallurgy (PM) methods have been commonly employed to produce high-purity alloys, with accurate chemical composition, targeted structures and controlled porosity [8]. Indeed, several studies have emphasized the PM effect on the tribological and electrochemical properties of CoCrMo alloys. Recently, there was a particular focus on improving the tribological behavior of implant materials [9].

The electrochemical characterization and corrosion resistance of CoCrMo alloys were studied by Zuraidawani Che Daud et al. They verified the electrochemical behavior of CoCrMo alloy in a $0.9 \%$ sodium chloride solution and found that the sintering regime had a significant impact on the corrosion resistance [10].

In addition, a study was carried out on the electrochemical properties of the CoCrMo alloy elaborated by the powder metallurgy process. The obtained results have shown that the main parameter to be monitored is the sintering temperature. In fact, the sintering temperature significantly affects the mechanical strength and electrochemical behavior of these alloys in the Ringer's solution [11].

The aim of this work is to study the structural and tribological properties as well as the electrochemical corrosion behavior of the CoCrMo alloy elaborated by sintering.

\section{EXPERIMENTAL METHODS}

\section{Materials Preparation}

7 he CoCrMo alloy was synthesized by the powder metallurgy (PM) process. The initial powders are Cobalt, Chromium and Molybdenum with a particle size: $\operatorname{Co}(99.5 \%$ purity, $45 \mu \mathrm{m}), \operatorname{Cr}(99.9 \%$ purity, $32 \mu \mathrm{m})$ and $M o(99.9 \%$ purity, $2 \mu \mathrm{m})$. The chemical composition of this alloy is given in the Tab. 1. All the samples were prepared according to ASTM F75 [2]. The elementary powders mixture was first kneaded in a ball mill at room temperature. Next, they were dried in an oven for $2 \mathrm{~h}$ at $80^{\circ} \mathrm{C}$ to eliminate all the moisture molecules adsorbed on the surface. After that, the mixture was uniaxial cold compacted in a tungsten carbide matrix carbide die under a seven ton load to produce cylindrical specimens $(13 \mathrm{~mm}$ in diameter and $4 \mathrm{~mm}$ in height). To prevent samples contamination, the pellets were placed into ceramic crucibles, and sintered at different temperatures of $1200^{\circ} \mathrm{C}, 1250^{\circ} \mathrm{C}$ and $1300^{\circ} \mathrm{C}$ for $2 \mathrm{~h}$, with subsequent cooling in the oven at an average speed of $20^{\circ} \mathrm{C} / \mathrm{min}$ to avoid oxidation. The sintering was carried out in an electric furnace under a hydrogen atmosphere. In order to perform the analytical tests, all specimens were polished after sintering.

\begin{tabular}{ccccc}
\hline Element & Co & Cr & Mo & Impurities \\
Weight $[\%]$ & Bal. & 28 & 6 & Fe, Cu<1 \\
\hline
\end{tabular}

Table 1: Chemical composition of the CoCrMo alloy powder (wt. \%).

\section{Characterizations: Microstructure, X-ray Diffraction (XRD) and Mechanical Properties}

The microstructure of CoCrMo alloys were analyzed by JEOL JSM-6830 scanning electron microscope (SEM). The phase identification was done by $\mathrm{X}$-ray diffraction using a RigakuUltima IV type diffractometer with a conventional radiation source Copper $\mathrm{Cu} \mathrm{K} \alpha(\lambda=1.5418 \AA)$ applying a voltage of $40 \mathrm{kV}$ and a current of $40 \mathrm{~mA}$. The X-ray diffraction patterns were compared to the ICSD Database. For mechanical characterization, Vickers microhardness measurements were carried out 
under $100 \mathrm{~g}$ load $\left(\mathrm{HV}_{0.1}\right.$, dwell time 15 seconds) using a microdurometer tester (INNOVATEST). The porosity rate was calculated using formula (1)[12]:

$$
p(\%)=\left[1-\left(\frac{\rho}{\rho t h}\right)\right] .100
$$

where: $\rho_{\text {th }}$ : theoretical density and $\rho$ : experimental density.

\section{Characterizations: Tribological Tests}

In accordance with ASTM G 99-95a and DIN 50324 standards, the tribological characteristics were assessed using a CSMInstrument tribometer in the ball-disc configuration, and the tests were performed in dry conditions. The alumina ball $\left(\mathrm{Al}_{2} \mathrm{O}_{3}\right)$ was selected as an antagonist with a hardness of $16 \mathrm{GPa}$ and $6 \mathrm{~mm}$ in diameter. After each friction test, the surface condition was analyzed by scanning electron microscope analysis. A profilometer 3D Cyber Technology CT100 model (laser source) was employed to measure the depth and the width of the wear groove. Tab. 2 summarizes the tribological test parameters. The wear rate was calculated using formula (2) proposed by Archard [13]. The ball-disc standard configuration is illustrated in Fig. 1.

$$
w=\frac{V}{F \cdot S}
$$

where: w: wear rate $\left(\mathrm{mm}^{3} / \mathrm{N} . \mathrm{m}\right)$; V: the wear volume $\left(\mathrm{mm}^{3}\right)$; F: applied load (N); S: total rotation distance $(\mathrm{m})$.

\begin{tabular}{lc}
\hline Applied load[N] & 5 \\
Linear speed [cm/s] & 1.08 \\
Stop conditions [m] & 30 \\
Radius [mm] & 4.90 \\
Atmosphere & Air \\
Temperature $\left[{ }^{\circ} \mathrm{C}\right]$ & 20.00 \\
Humidity $[\%]$ & 40.00 \\
\hline
\end{tabular}

Table 2: Parameters of tribological tests.

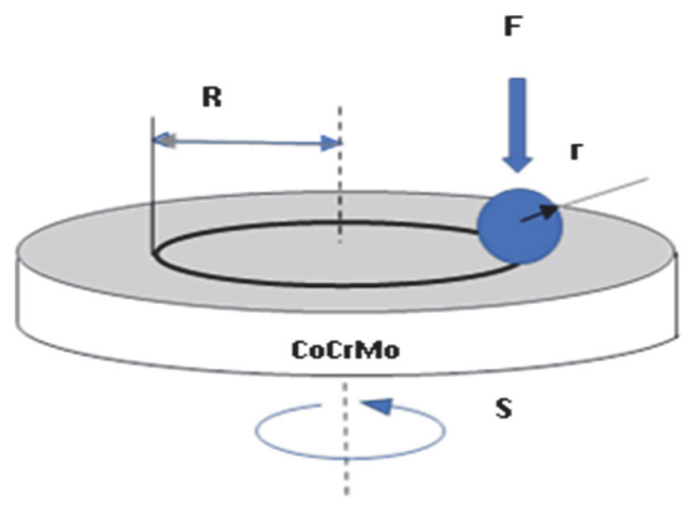

Figure 1: Standard configuration of the ball-disc.

\section{Characterizations: Electrochemical Corrosion Tests}

The electrochemical measurements were performed using a Biologic SP300 type Potentiostat/Galvanostat controlled by an EC-Lab V10.40 analyzer to study the corrosion behavior of CoCrMo alloy in simulated body fluid. The experiments were conducted using a conventional three-electrode cell with the saturated calomel electrode (SCE) as the reference electrode, platinum wire (Pt) as the auxiliary electrode, and CoCrMo alloy as the working electrode. The electrochemical experiments were performed in a physiological medium 0 [14]. The composition of the Hank's solution is shown in Tab. 3. 
The potential monitoring was made in open circuit (OCP) for $60 \mathrm{~min}$. The Potentiodynamic polarization tests were performed by scanning the applied potential from -1 to $1.2 \mathrm{~V} / \mathrm{SCE}$ at a scan rate of $1 \mathrm{mV} . \mathrm{s}^{-1}$.

The corrosion potential $\mathrm{E}_{\text {corr }}$ as well as the current density of corrosion $\mathrm{I}_{\text {corr }}$ were extrapolated from the Tafel curves slope using EC-labV11.20 software. The electrochemical impedance spectroscopy (EIS) tests were carried out in the frequency range of $100 \mathrm{kHz}$ to $10 \mathrm{mHz}$ with amplitude of $0 \pm 10 \mathrm{mV}$.

\begin{tabular}{cccccccccc}
\hline Substance & $\mathrm{NaCl}$ & $\mathrm{KCl} \mathrm{NaHCO} 3$ & $\mathrm{NaH}_{2} \mathrm{PO}_{4} . \mathrm{H}_{2} \mathrm{O}$ & $\mathrm{Na}_{2} \mathrm{HPO}_{4} .2 \mathrm{H}_{2} \mathrm{O}$ & $\mathrm{CaCl}_{2} .2 \mathrm{H}_{2} \mathrm{O}$ & $\mathrm{MgCl}_{2}$ & $\mathrm{MgS}_{4} .7 \mathrm{H}_{2} \mathrm{O}$ & $\mathrm{Glucose}$ \\
$\begin{array}{c}\text { Composition } \\
{[\mathrm{g} / \mathrm{L}]}\end{array}$ & 8.0 & 0.4 & 0.35 & 0.25 & 0.06 & 0.19 & 0.19 & 0.06 & 1 \\
\hline
\end{tabular}

Table 3: Composition of Hank's solution.

\section{RESULTS AND DISCUSSIONS}

\section{XRD Analysis and Microstructure}

T -ray patterns of CoCrMo samples (Fig. 2) show that the three samples (a, b, c) are mainly composed of two phases: The $\gamma$-Co phase with a cubic structure, fcc (JCPDS 00-001-1277) and the $\varepsilon$-Co phase with a hexagonal structure, hcp 1 (JCPDS 00-015-0806). The results are in good agreement with existing phases in the Co-Cr binary equilibrium diagram [1]. For all samples, the peak intensity of (111) fcc is higher than that of the (101) hcp. Moreover, the presence of diffraction peak with low intensity corresponding to the $\varepsilon$-Co phase (101) indicates that all the samples contain a small amount of $\varepsilon$-Co phase [15].

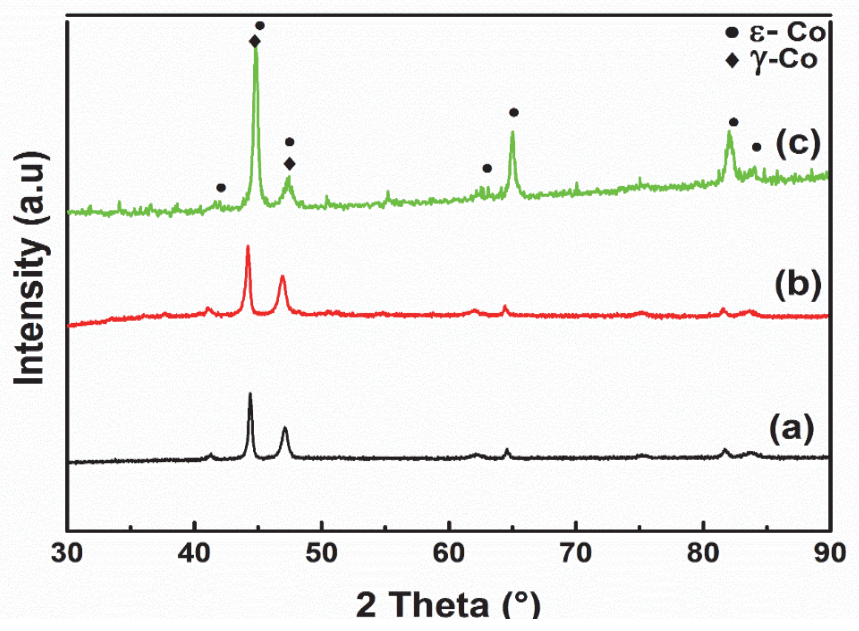

Figure 2: X-Ray diffraction patterns of CoCrMo alloys sintered: (a) $1200^{\circ} \mathrm{C}$, (b) $1250^{\circ} \mathrm{C}$, (c) $1300^{\circ} \mathrm{C}$.

Otherwise, no additional diffraction or offset peaks were observed for the studied CoCrMo samples sintered at different temperatures. The microstructure of the sintered CoCrMo alloy at different temperatures is given in Fig. 3. These figures show that depending on the contrast, there were three types of phases in the CoCrMo alloy, i.e. gray, dark and shiny phases. Calculations of the volume proportions of each of the obtuse phases are done using the HighScore Plus software version (3.0.4). The results of the phase volume fractions obtained show a variation in the volume proportion of the $\varepsilon$-Co phase ranging from $51.1 \%, 58.7 \%$ and $63.1 \%$ for the samples sintered at $1200^{\circ} \mathrm{C}$, and $1250^{\circ} \mathrm{C}$ and $1300^{\circ} \mathrm{C}$. respectively. We note the presence of the majority Co phase which constitutes the matrix of gray color. In the matrix, we also notice regions of dark lamellar morphology rich in chromium and light zones rich in molybdenum. No carbides are present in the microstructure, which corresponds well to the DRX of the CoCrMo alloy identified in Fig. 2. The sintering temperature in our sample does not affect the nature of the formed phases, but rather the volume fraction of the existing phases. 

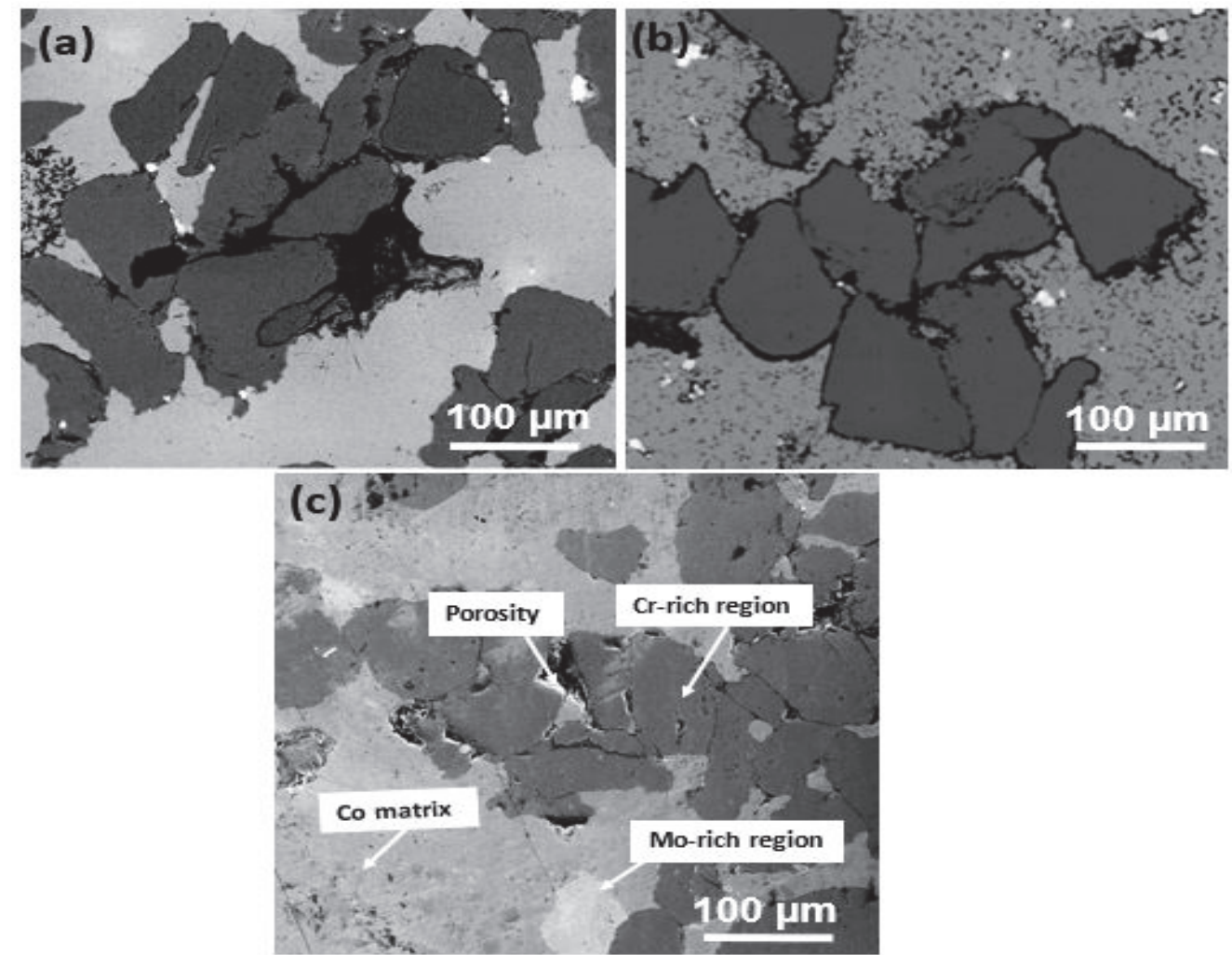

Figure 3: SEM images of CoCrMo alloys sintered: (a) $1200^{\circ} \mathrm{C}$, (b) $1250^{\circ} \mathrm{C}$, (c) $1300^{\circ} \mathrm{C}$.

\section{Density Evolution and Microhardness}

Tab. 4 summarizes the experimental values of density and micro-hardness of the sintered samples. One observes that these two properties increase with the sintering temperature. The highest values of relative density $91 \%$ and hardness of $384 \mathrm{HV}_{0.1}$ were obtained for the sample sintered at $1300^{\circ} \mathrm{C}$. This is mainly due to an increased formation of collars between the particles (depends on the diffusion phenomena). As more necks were forming with increasing sintering temperature. Diffusion mechanisms become active at higher temperatures during heating process. This fact leads to porosity reduction and automatically affects hardness.

\begin{tabular}{llll}
\hline Sintering temperature $\left[{ }^{\circ} \mathrm{C}\right]$ & 1200 & 1250 & 1300 \\
Experimental density $\left[\mathrm{g} / \mathrm{cm}^{3}\right]$ & 7.520 & 7.710 & 8.020 \\
Porosity [\%] & 15 & 13 & 9 \\
Microhardness $\mathrm{HV}_{0.1}$ & 219 & 334 & 384 \\
\hline
\end{tabular}

Table 4: Experimental density, porosity and microhardness of the CoCrMo alloy

The hardness result from our samples is greater than that obtained from Zuraidawani Che Daud et al [16]. The highest rate in terms of porosity is obtained from a sample sintered at $1200^{\circ} \mathrm{C}$. In fact, mechanical and microstructural properties of the sintered alloy CoCrMo are strongly dependent on the heat treatment parameters (sintering).

Generally biomedical materials require a certain degree of porosity, Pores are important for tissue formation, as they allow cell migration and proliferation, as well as vascularization [17].

\section{Tribological Behavior: Coefficient of Friction}

The evolution of the coefficient of friction (COF) in the CoCrMo alloy as a function of the friction distance for various temperatures is presented in Fig. 4(a). The analysis of these curves makes it possible to distinguish four successive periods of friction. The first period (I) of friction corresponds to the running-in regime, because the surfaces adapt to each other and the surface roughness is reduced by the plastic deformation. The second period (II) corresponds to a slight decrease in the coefficient of friction, as the wear particles cannot easily anchor a polished surface due to the decrease in roughness deformation. The third period (III) is defined by a substantial rise in the coefficient of friction. The third body which 
fragments and oxidizes most possibly to serve an abrasive role and, finally the fourth period (IV) corresponds to the stationary phase or the stabilized regime corresponding to the stabilization of the coefficient of friction where its value is maintained constant during the test[18].

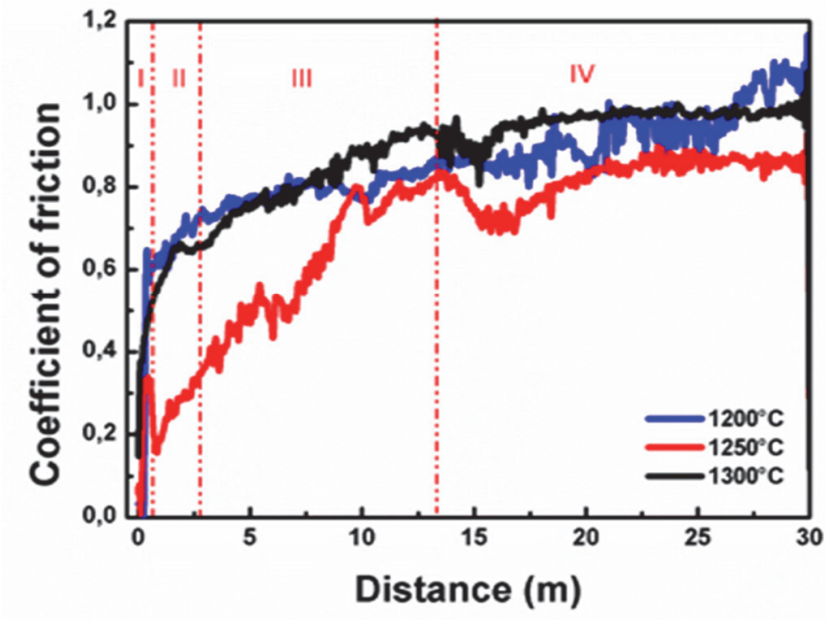

(a)

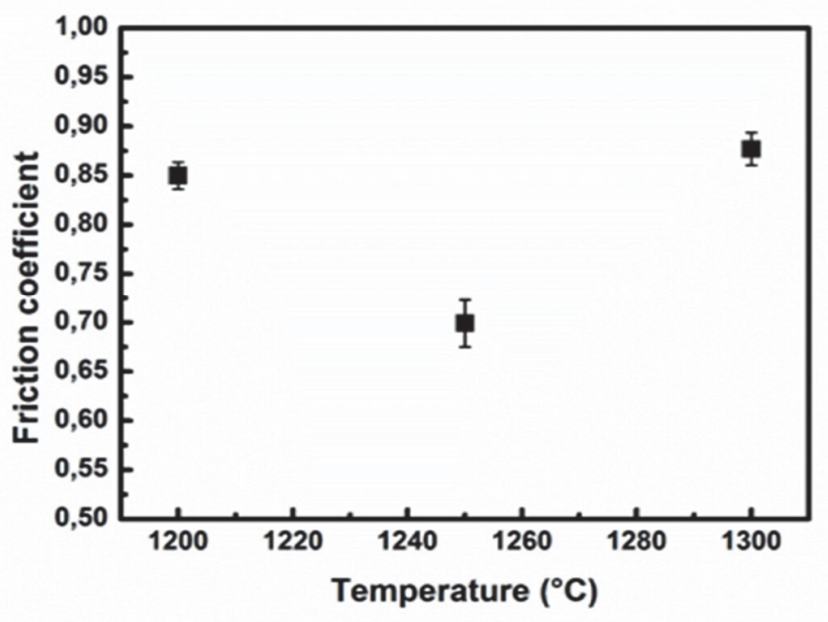

(b)

Figure 4: (a) Evolution of Coefficient of friction and (b) Average friction coefficients of the CoCrMo alloy sintered at different temperatures.

The average values of the friction coefficient of the samples CoCrMo sintered at different temperatures are shown in Fig. 4(b). A slight decrease in friction coefficient values, with the sintering temperature increasing from $1200^{\circ} \mathrm{C}$ to $1250^{\circ} \mathrm{C}$. This is mainly due to the increase in the sintering temperature which leads to the increase in hardness and density. So, for a sample sintered at $1200^{\circ} \mathrm{C}$, we go from a hardness of $219 \mathrm{HV}$ to a hardness of $334 \mathrm{HV}$ for a sample sintered at $1250^{\circ} \mathrm{C}$. On the other hand, for the sample sintered at $1300^{\circ} \mathrm{C}$, it has a high coefficient of friction although it has a higher hardness. This is probably due to the formation of solid wear debris (third-body particles) during the friction process and thus contributes to the increase in the coefficient of friction. In addition, this fact is indicative of the beginning of the particle detachment from the metallic material to the alumina ball's outer surface (Fig. 5). In fact, the contact form changes every time from two bodies (Alumina-Sample) to that of three bodies (Debris-Alumina-Sample) [19]

\section{Wear Rate}

Fig. 5 depicts the evolution of the specific wear rate of the CoCrMo samples elaborated by PM as a function of the different sintering temperatures. It can be shown that the sintering temperature has a positive effect on the reduction in the wear. The wear phenomenon is a surface degradation by friction during operating cycle. When the system is subject to stresses, various types of damage can take place according to the intensity of the stresses applied. Since these stresses locally exceed the yield strength of one of the two materials in contact, the latter is deformed either plastically (ductile material) or going to flake or crack (brittle material) after a few operating cycles.

On the other hand, the wear behavior can be explained by the effect of porosity, the presence of pores within sintered materials decreases the actual contact area between the two materials in contact, thus increasing the contact pressure and promote the detachment of particles during sliding. As a result, causing wear debris to form during sliding, cracks appear next to the pores.

The wear resistance and the coefficient of friction are thus reduced, this is mainly due to an increased formation of collars between the particles (depends on the diffusion phenomena). As more necks formed with increasing sintering temperature. Diffusion mechanisms become active during the high temperature heating process, cause porosity reduction and automatically affect hardness.

As can be seen in Fig. 5, the wear rate decreases from $2.394 \times 10^{-4} \mathrm{~mm}^{3} /(\mathrm{Nm})$ to $2.233 \times 10^{-4} \mathrm{~mm}^{3} /(\mathrm{Nm})$ when the sintering temperature increases from $1200^{\circ} \mathrm{C}$ to $1250^{\circ} \mathrm{C}$.

For samples sintered at $1300{ }^{\circ} \mathrm{C}$, exhibits a porosity rate of around $9 \%$, this sample exhibits a porosity that is mostly closed. It therefore behaves like a dense material, which explains the low values obtained for the wear rate $(0.987 \times 10-4 \mathrm{~mm} 3 / \mathrm{Nm})$. A good correlation between the wear rate values and the mechanical properties obtained for the sintered compacts at 
different temperatures in this analysis. The higher the sintering temperature, the more the porosity decreases, which provides good wear resistance for the sample sintered at the highest temperature $\left(1300^{\circ} \mathrm{C}\right)$.

In fact, the structure and hardness have been reported to have a significant impact on the wear behavior of this alloy [20]. In Our work, we predict that a fraction of the wear debris can remain attached to against an alumina ball. Transfer of material to the contact surface of the counterface (alumina ball) was clearly visible in Fig. 6. The findings of the 3D surface analysis of the worn surface's wear traces are shown in the Fig. 7. These findings support the presence of a contact trace on the sample's surface. This illustration depicts numerous grooves of various widths and depths.

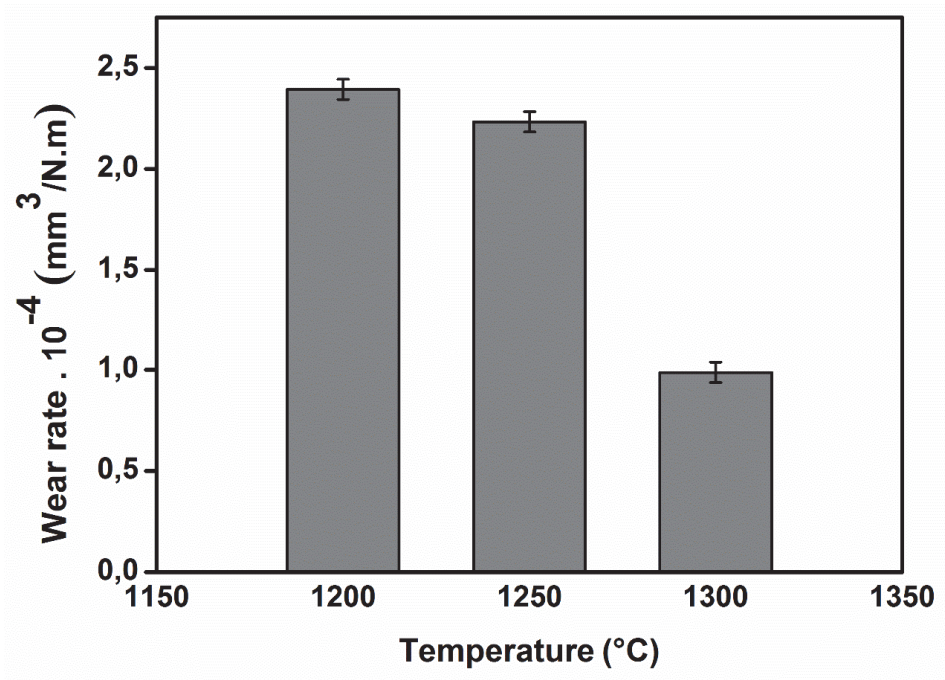

Figure 5: Wear rate after dry friction test of CoCrMo alloy sintered at different temperatures.
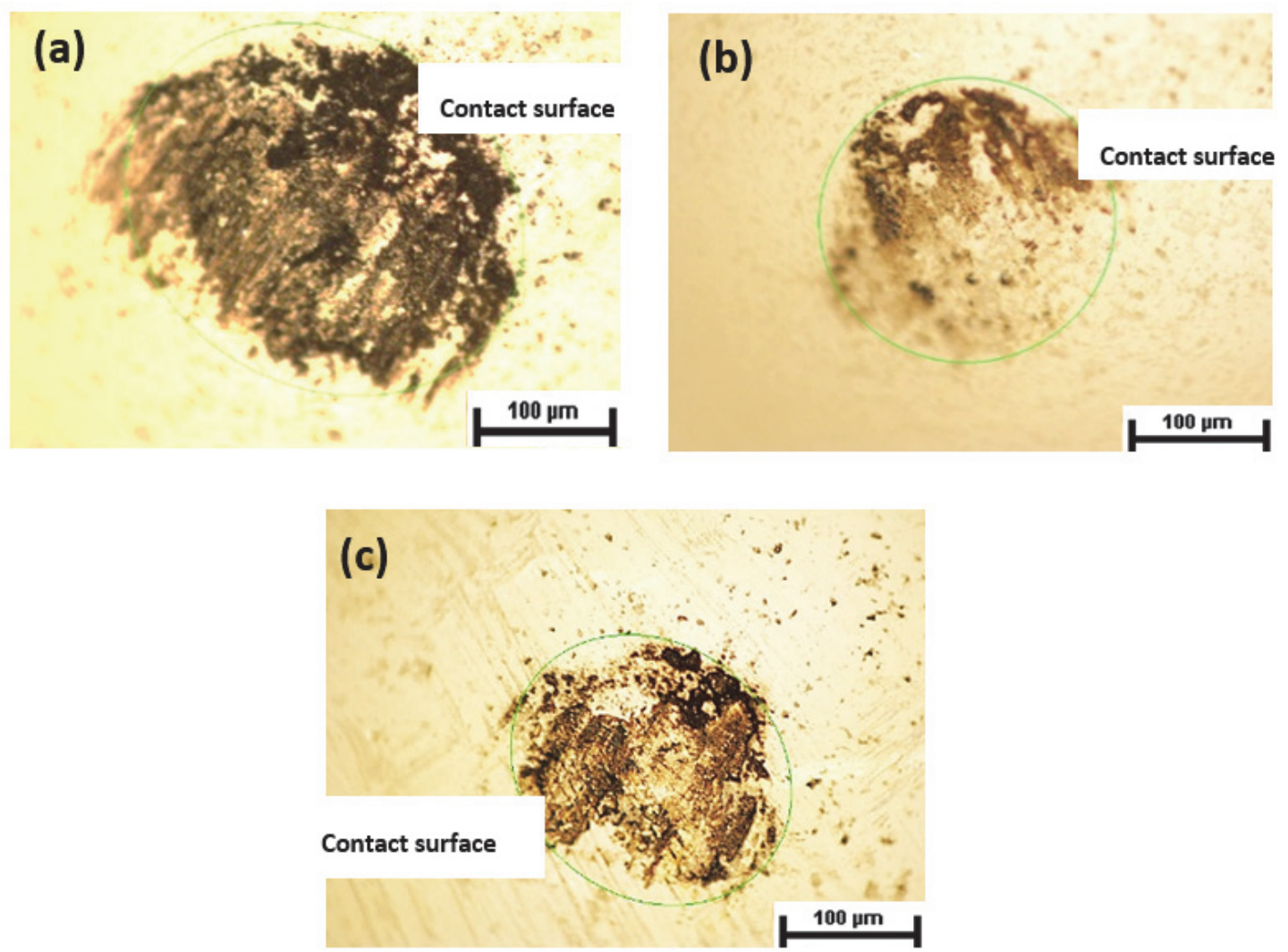

Figure 6: Optical micrographs of wear marks on the alumina ball: (a) $1200^{\circ} \mathrm{C}$, (b) $1250^{\circ} \mathrm{C}$ and (c) $1300^{\circ} \mathrm{C}$. 

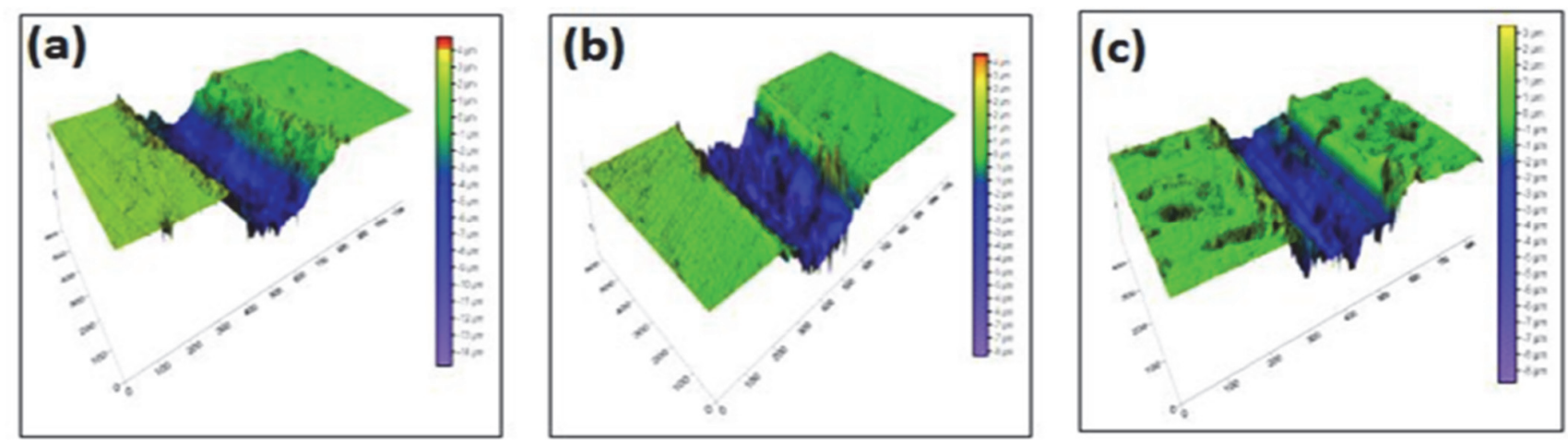

Figure 7: 3D images of the worn surface of the CoCrMo alloy samples sintered: (a) $1200^{\circ} \mathrm{C}$, (b) $1250^{\circ} \mathrm{C}$ and (c) $1300^{\circ} \mathrm{C}$.

Wear Surface and Wear Mechanism

The SEM images (Fig. 8) shows the morphology of the worn surfaces of the samples allowing the identification of the wear mechanisms that intervene during friction. All of the sintered samples studied show significant damage to their surfaces, with a distorted appearance (Fig. 8a, 8b and 8c). Indeed, grooves parallel to the direction of sliding or imprints left by hard particles on the surface of the samples are clearly visible, wear debris (third body) was also observed in the two samples sintered at $1200^{\circ} \mathrm{C}$ and $1250{ }^{\circ} \mathrm{C}$. Examination of these tracks reveals the presence of scratches and grooves parallel to the sliding direction that are typical characteristics of abrasive wear [21]. We also note for the sample sintered at $1300^{\circ} \mathrm{C}$ (fig. $8 c$ ), that the scratches parallel to the sliding direction are always present. A detachment of small chips was observed on the surface, especially at the periphery of the trace of contact. This phenomenon indicates a degradation mechanism based on plastic deformation and brittle fracture of the surface linked to the hardness of the alloy.

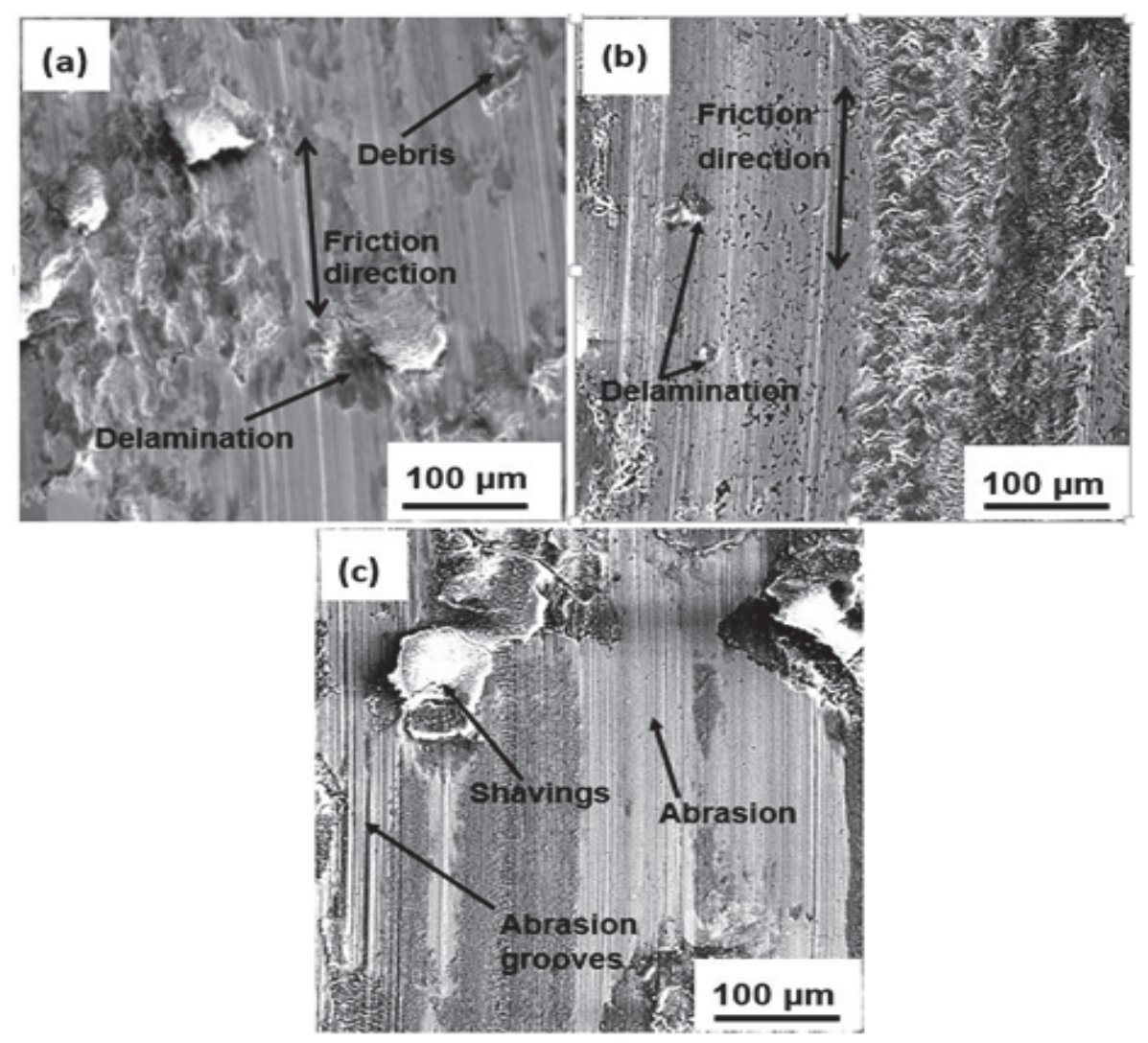

Figure 8: SEM micrographs of the wear tracks on the surface of the CoCrMo alloy sintered at different temperatures: (a) $1200^{\circ} \mathrm{C}$, (b) $1250^{\circ} \mathrm{C}$ and (c) $1300^{\circ} \mathrm{C}$. 
In this work we introduce the plowing effect that occurs when one of the two materials in contact is much more difficult to create furrows on the contact surface of the softer material. The hardness ratios (ball of alumina / CoCrMo) at different temperatures are $(2400 / 219 \mathrm{HV}),(2400 / 334 \mathrm{HV})$ and $(2400 / 384 \mathrm{HV})$, respectively. In addition, tough roughness can sink into the soft body, creating a groove through the plastic flow of the material. This phenomenon induces resistance to movement [22].

\section{Corrosion Behavior: Electrochemical Properties}

In order to study the corrosive behavior of CoCrMo alloy samples sintered at different temperatures, we started by tracking the abandonment potential $\left(\mathrm{E}_{\mathrm{ocp}}\right)$ using plotting potential-time curves (Fig. 9 a). These curves suggest that a stable value is not immediately reached by the open circuit potential. Experiments show that it stabilizes after 15 minutes of immersion. For the samples sintered at $1300^{\circ} \mathrm{C}$, the equilibrium potential increases towards positive values, and then it stabilizes at $-497 \mathrm{mV}$. However, the potential for samples sintered at $1200^{\circ} \mathrm{C}$ and $1250^{\circ} \mathrm{C}$ increases sharply and then decreases to stabilize at $-512 \mathrm{mV}$ and $-499 \mathrm{mV}$, respectively. Therefore, we can conclude that the increase in the potential at the beginning of the experiments is related to the electrochemical reaction that occurs between the sample surface and the solution.

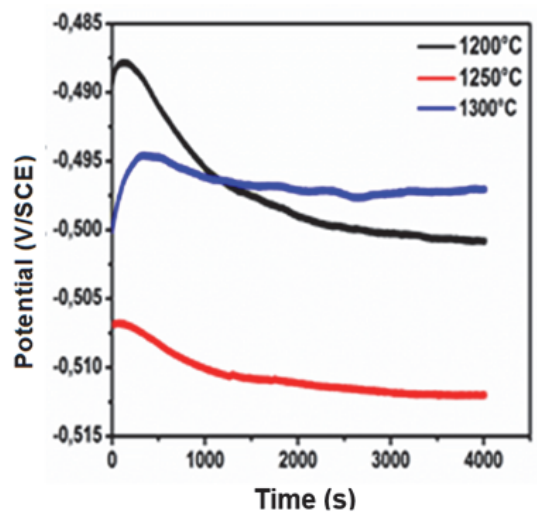

(a)

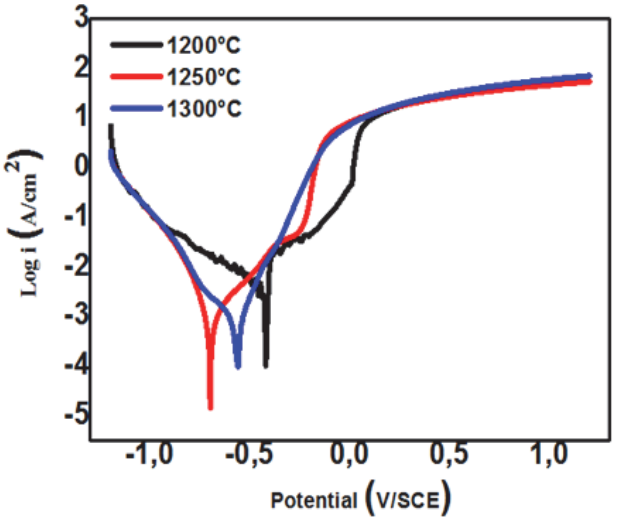

(b)

Figure 9: Electrochemical Curve of CoCrMo alloy in Hank's solution: (a) Eocp curves,(b) Potentiodynamic Polarization curves.

Moreover, obtaining the constant OCP value after immersion means that the formation of the protective layer of oxide (Passive film formation of $\mathrm{Cr}_{2} \mathrm{O}_{3}$ ) has been completed [23]. The potentiodynamic curves provide useful information on the kinetics of the multiple-composed corrosion mechanism (charge transfer, mass transfer, and species adsorption). Fig. 9.b. represents the potentiodynamic curves of CoCrMo alloys sintered at different temperatures. Three typical potential domains can be observed in the anodic region. A short passivation zone accompanied by an increase in current density due to the passive film rupture corresponds to the first domain.

The current density related to the reformation of passive film in the third region and its stability [24].

Tab. 5 lists the various electrochemical parameters obtained from these curves, such as the corrosion potential ( $\mathrm{E}_{\mathrm{corr}}$ ), the corrosion current $\left(\mathrm{I}_{\text {corr }}\right)$ and the corrosion rate $\left(\mathrm{V}_{\text {corr }}\right)$. The highest corrosion current density $\left(14.08 \mu \mathrm{A} / \mathrm{cm}^{2}\right)$ was obtained for CoCrMo sample sintered at $1200^{\circ} \mathrm{C}$, while, the lowest value was obtained for the alloy sintered at $1300^{\circ} \mathrm{C}$ $\left(0.775 \mu \mathrm{A} / \mathrm{cm}^{2}\right)$. This fact may be attributed to the influence of the porosity on the corrosion resistance.

\begin{tabular}{ccccc}
\hline $\begin{array}{c}\text { Temperature } \\
{\left[{ }^{\circ} \mathrm{C}\right]}\end{array}$ & $\mathrm{E}_{\text {corr }}[\mathrm{mV}]$ & $\mathrm{I}_{\text {corr }}\left[\mu \mathrm{A} / \mathrm{cm}^{2}\right]$ & $\begin{array}{c}\mathrm{V}_{\text {corr }} \\
{[\mathrm{mm} / \text { year }]}\end{array}$ & $\mathrm{R}_{\mathrm{p}}[\mathrm{Ohm}]$ \\
1200 & -420 & 14.087 & 0.0850 & 2642 \\
1250 & -698 & 1.070 & 0.0064 & 31387 \\
1300 & -563 & 0.775 & 0.0047 & 34527 \\
\hline
\end{tabular}

Table 5: Corrosion parameters of CoCrMo alloy after electrochemical tests. 
The higher the sintering temperature, the lower the porosity, which results higher corrosion resistance. Therefore, the corrosion rate is proportional to the density of the corrosion current [25]. It should be noted that for a sample sintered at $1300^{\circ} \mathrm{C}$, the shift of the corrosion potential towards more noble. Values can be due to two factors [26]. The first factor refers to the higher surface energy of the alloy. The second factor is related to the surface layer oxidation. In this case, the protection is provided by the thickening of the oxide film. In fact, the passivation of the CoCrMo alloy is linked to the formation of a thin layer mainly formed of chromium oxide $\left(\mathrm{Cr}_{2} \mathrm{O}_{3}\right)$ and certain hydroxides [27]. This layer prevents the exchange of oxygen and metal ions.

\section{Electrochemical Impedance Spectroscopy}

The EIS measurements were carried out at the open circuit potential (OCP) after 360 minutes of immersion in Hank's solution. Fig. 10 (a) illustrates the Nyquist diagram for the CoCrMo alloy sintered at different temperatures. It can be seen that the impedance spectra exhibit an incomplete semi-circle at mid and high frequencies. The absolute impedance curve at high frequencies $(10,000-0.1 \mathrm{~Hz})$ is almost independent of frequency with a phase angle of $0^{\circ}$, chowing electrolyte resistance (Rs). This suggests a capacitive behavior of the CoCrMo electrode in the corrosion solution. It is well known that the radius of the semicircular arc is linked to the polarization resistance of the passive film. This behavior indicates the formation of a stable oxide film on the surface of the alloy. According to the impedance measurements, the best passive properties were obtained from the alloy sintered at $1300^{\circ} \mathrm{C}$ compared to other samples sintered at $1250^{\circ} \mathrm{C}$ and $1200^{\circ} \mathrm{C}$, respectively.

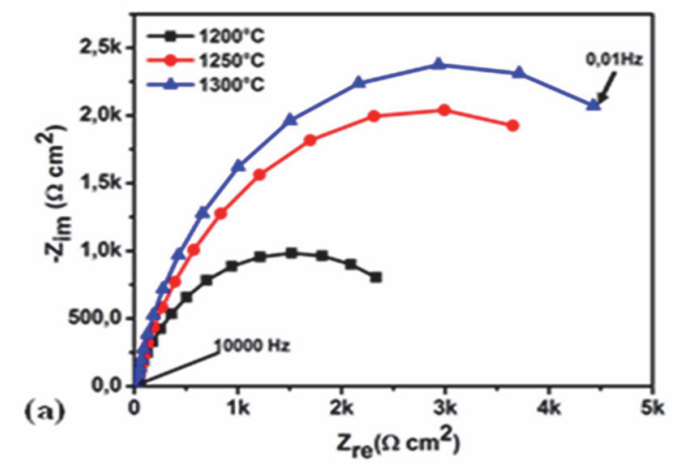

(b)

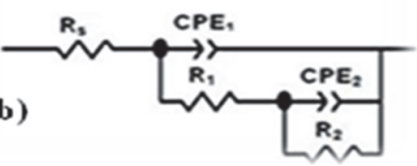

Figure 10: Nyquist diagram sintered alloy in the Hank's solution and Equivalent electrical circuit used for the simulation of the impedance data of the CoCrMo alloy.

The results thus obtained confirm the positive influence of the sintering temperature on the corrosion resistance. In a previous study, the capacitive behavior at the metal/electrolyte interface was shown to be primarily due to the formation of an oxide film on the surface of these alloys [28]. The closing appearance of the capacitive loop indicates that the surface is covered with a two-layer oxide film, mainly a compact inner layer and a porous outer layer. Tab. 6 summarizes the analysis of experimental impedance data using the EC-Lab software. The goodness-of-fit was evaluated by the values of $\left(\chi^{2}\right)$ that were in the range of $10^{-3}$. The data were adjusted with the equivalent electrical circuit (EEC) depicted in Fig. 10 (b). This circuit has already been proposed by many authors [29].

\begin{tabular}{cccccccc}
\hline $\begin{array}{c}\text { Temperature } \\
{\left[{ }^{\circ} \mathrm{C}\right]}\end{array}$ & $\begin{array}{c}\mathrm{R}_{\mathrm{s}} \\
{\left[\Omega \mathrm{cm}^{2}\right]}\end{array}$ & $\begin{array}{c}\mathrm{CPE}_{1} \cdot 10^{-3} \\
{\left[\mathrm{Fcm}^{-2}\right]}\end{array}$ & $\mathrm{n}_{1}$ & $\begin{array}{c}\mathrm{R}_{1} \\
{\left[\Omega \mathrm{cm}^{2}\right]}\end{array}$ & $\begin{array}{c}\mathrm{CPE}_{2} \cdot 10^{-3} \\
{\left[\mathrm{Fcm}^{-2}\right]}\end{array}$ & $\begin{array}{c}\mathrm{R}_{2} \\
{\left[\Omega \mathrm{cm}^{2}\right]}\end{array}$ & $\mathrm{n}_{2}$ \\
1200 & 26 & 0.573 & 0.9 & 445 & 0.230 & 1300 & 0.7 \\
1250 & 23 & 0.721 & 0.9 & 1978 & 0.196 & 3309 & 0.8 \\
1300 & 20 & 0.746 & 0.9 & 264 & 0.133 & 5823 & 0.8 \\
\hline
\end{tabular}

Table 6: Electrical parameters of the equivalent circuit of the sintered CoCrMo alloy in Hank's solution.

The proposed model is composed of the solution resistance (Rs) arranged in series with two parallel combinations

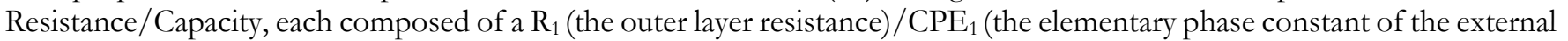
film) and $\mathrm{R}_{2}$ (the inner layer resistance)/CPE (the elementary phase constant of the internal film). The resistance values of the inner layer that acts as a compact barrier are much higher than those of the outer porous layer. This indicates that the 
protection offered by the passive layer is mainly due to that of the internal barrier layer [45]. The larger capacitive loop usually leads to better corrosion resistance [30]. So, it should be noted that the sample sintered at $1300^{\circ} \mathrm{C}$ exhibited a higher polarization resistance. In fact, this resistance is the sum of two resistances: namely the resistance of the porous layer and the compact barrier resistance. The results thus obtained are in a good agreement of those obtained from the polarization curves.

\section{CONCLUSION}

7 his paper investigates the influence of the sintering temperature on the microstructural, tribological and electrochemical properties of the CoCrMo alloy. The main conclusions are listed below:

1. Higher densification (porosity of up to $9 \%$ ) was obtained at high sintering temperature of $1300^{\circ} \mathrm{C}$ compared to $1200^{\circ} \mathrm{C}$ and $1250^{\circ} \mathrm{C}$.

2. The samples sintered at $1300^{\circ} \mathrm{C}$ exhibited better wear resistance with a wear rate of $0.987 \times 10^{-4} \mathrm{~mm}^{3} / \mathrm{Nm}$.

3. In terms of electrochemical behavior, the samples sintered at $1300^{\circ} \mathrm{C}$ displayed higher corrosion resistance with a corrosion rate of $0.0047 \mathrm{~mm} /$ year compared to samples sintered at $1200^{\circ} \mathrm{C}$ and $1250^{\circ} \mathrm{C}$, respectively.

4. The results of the electrochemical impedance tests in the hank's solution confirmed the capacitive behavior of the alloy by the formation of a film composed of two layers, a compact inner layer and another porous outer one.

5. The CoCrMo alloy sintered at $1300^{\circ} \mathrm{C}$ yielded the best performance in terms of tribological and electrochemical.

6. The assessment of the effect of the sintering temperature is an important feature for alloy development.

\section{REFERENCES}

[1] Bandyopadhyay, A., Shivaram, A., Isik, M., Avila, J. D., Dernell, W. S. and Bose, S. (2019). Additively manufactured calcium phosphate reinforced CoCrMo alloy: Bio-tribological and biocompatibility evaluation for load-bearing implants. Addit. Manuf, 28, pp. 312-324. DOI: 10.1016/j.addma.2019.04.020.

[2] Toh, W. Q., Tan, X., Bhowmik, A., Liu, E. and Tor, S. B. (2017). Tribochemical characterization and tribocorrosive behavior of CoCrMo alloys: A review. Materials, 11(1). DOI: 10.3390/ma11010030.

[3] Liu, Y.,\& Gilbert, J. L. (2017). The effect of simulated inflammatory conditions and pH on fretting corrosion of CoCrMo alloy surfaces. Wear, 390, pp. 302-311. DOI: 10.1016/j.wear.2017.08.011.

[4] Stojanović, B., Bauer, C., Stotter, C., Klestil, T., Nehrer, S., Franek, F. and Rodríguez Ripoll, M. (2019). Tribocorrosion of a CoCrMo alloy sliding against articular cartilage and the impact of metal ion release on chondrocytes. Acta Biomater, 94, pp. 597-609. DOI: 10.1016/j.actbio.2019.06.015.

[5] de Castro Girão, D., Béreš, M., Jardini, A. L., Filho, R. M., Silva, C. C., de Siervo, A., Araújo, W. S. (2020). An assessment of biomedical CoCrMo alloy fabricated by direct metal laser sintering technique for implant applications. Mater. Sci. Eng. C, 107, pp. 110305. DOI: 10.1016/j.msec.2019.110305

[6] Li, H., Wang, M., Lou, D., Xia, W. and Fang, X. (2020). Microstructural features of biomedical cobalt-chromiummolybdenum (CoCrMo) alloy from powder bed fusion to aging heat treatment. J. Mater. Sci. Technol, 45, pp. 146156. DOI: $10.1016 /$ j.jmst.2019.11.031.

[7] Yamanaka, K., Mori, M. and Chiba, A. (2013). Nanoarchitectured Co-Cr-Mo orthopedic implant alloys: Nitrogenenhanced nanostructural evolution and its effect on phase stability. Acta Biomater, 9(4), pp. 6259-6267.

DOI: 10.1016/j.actbio.2012.12.013.

[8] Hermawan, H., Ramdan, D. and P. Djuansjah, J. R. (2011). Metals for Biomedical Applications. Biomedical Engineering - From Theory to Applications. DOI: 10.5772/19033.

[9] Varano, R., Bobyn, J. D., Medley, J. B. and Yue, S. (2006). Effect of microstructure on the dry sliding friction behavior of CoCrMo alloys used in metal-on-metal hip implants. J. Biomed. Mater. Res. - Part B Appl. Biomater, 76(2), pp. 281286. DOI: $10.1002 /$ jbm.b.30370.

[10] Daud, Z. C., Jamaludin, S. B., Derman, M. N. and Wahab, J. A. (2013). The corrosion studies of powder metallurgy CoCr-Mo (F-75) alloy. Adv. Environ. Biol, 7, pp. 3716-3719.

[11] Rodrigues, W. C., Broilo, L. R., Schaeffer, L., Knörnschild, G. and Espinoza, F. R. M. (2011). Powder metallurgical processing of Co-28\%Cr-6\%Mo for dental implants: Physical, mechanical and electrochemical properties. Powder Technol, 206(3), pp. 233-238. DOI: 10.1016/j.powtec.2010.09.024. 
[12] Thümmler, F. and Oberacker, R. (1993). An Introduction to Powder Metallurgy (Series Edi). The Institute of Materials, London.

[13] Ren, F., Zhu, W. and Chu, K. (2016). Fabrication, tribological and corrosion behaviors of ultra-fine grained Co-28Cr6Mo alloy for biomedical applications. J. Mech. Behav. Biomed. Mater, pp. 60, 139-147. DOI: $10.1016 /$ j.jmbbm.2015.12.039.

[14] Manivasagam, G., Dhinasekaran, D. and Rajamanickam, A. (2010). Biomedical Implants: Corrosion and its Prevention - A Review,Recent Patents Corros. Sci, 2(1), pp. 40-54. DOI: 10.2174/1877610801002010040.

[15] Mehmet Yildırım, AK. (2018). Production of Co-Cr-Mo Biomedical Alloys via Investment Casting Technique. Turk. J. Electrom. Energ, 3(1).

[16] Daud, Z. C., Jamaludin, S. B. and Bari, F. (2011). Characterization of Co-Cr-Mo (F-75) alloy produced by solid state sintering. Adv. Mater. Res, 173, pp. 106-110. DOI: 10.4028/www.scientific.net/AMR.173.106.

[17] Mour, M., Das, D., Winkler, T., Hoenig, E., Mielke, G., Morlock, M. M. and Schilling, A. F. (2010). Advances in porous biomaterials for dental and orthopaedic applications. Materials, 3(5), pp. 2947-2974. DOI: 10.3390/ma3052947.

[18] Buciumeanu, M., Bagheri, A., Souza, J. C. M., Silva, F. S. and Henriques, B. (2016). Tribocorrosion behavior of hot pressed CoCrMo alloys in artificial saliva. Tribol. Int, 97, 423-430. DOI: 10.1016/j.triboint.2016.02.007.

[19] Fellah, M., Aissani, L., Iost, A., Zairi, A., Montagne, A. and Mejias, A. (2018). Friction and wear behavior of biomaterials alloys AISI 316L and Ti-6Al-7Nb for total hip prosthesis. Mater. Tech, 106(4). DOI: 10.1051/mattech/2018051

[20] Saldívar-García, A. J. and López, H. F. (2005). Microstructural effects on the wear resistance of wrought and as-cast Co-Cr-Mo-C implant alloys. J. Biomed. Mater. Res. - Part A, 74(2), pp. 269-274. DOI: 10.1002/jbm.a.30392.

[21] Cuao-Moreu, C. A., Hernández-Sanchéz, E., Alvarez-Vera, M., Garcia-Sanchez, E. O., Perez-Unzueta, A. and Hernandez-Rodriguez, M. A. L. (2019). Tribological behavior of borided surface on CoCrMo cast alloy. Wear, pp. 426427(September 2018), 204-211. DOI: 10.1016/j.wear.2019.02.006.

[22] Matthews, A. Holmberg, K. (1994). Coatings tribology: properties, techniques and applications in surface engineering, Elsevier. 28, pp. 33-124. DOI: 10.1016/S0167-8922(08)70753-3.

[23] Abbass, M. K. Yagoob, J. A. (2019). Corrosion Behavior and Mechanisms of Co-Cr-Mo Alloy Fabricated by Powder Metallurgy Route in Ringer's Solution. Tikrit Journal for Dental Sciences, 7(1), pp. 11-19.

[24] Thornley, B., Beadling, R., Bryant, M. and Neville, A. (2020). Investigation of the Repassivation Process of CoCrMo in Simulated Biological Fluids. Corrosion, 76(6), pp. 539-552. DOI: 10.5006/3423

[25] Ortega-Saenz, J. A., Hernandez-Rodriguez, M. A. L., Ventura-Sobrevilla, V., Michalczewski, R., Smolik, J. and Szczerek, M. (2011). Tribological and corrosion testing of surface engineered surgical grade CoCrMo alloy. Wear, 271(9-10), pp. 2125-2131. DOI: 10.1016/j.wear.2010.12.062.

[26] Songür, M., Çelikkan, H., Gökmeşe, F., Şimşek, S. A., Altun, N. Ş. and Aksu, M. L. (2009). Electrochemical corrosion properties of metal alloys used in orthopaedic implants. J. Appl. Electrochem., 39(8), pp. 1259-1265. DOI: 10.1007/s10800-009-9793-6.

[27] Lashgari, H. R., Kong, C., Asnavandi, M. and Zangeneh, S. (2018). The effect of friction stir processing (FSP) on the microstructure, nanomechanical and corrosion properties of low carbon CoCr28Mo5 alloy. Surf. Coatings Technol, 354, pp.390-404. DOI: 10.1016/j.surfcoat.2018.09.039

[28] Vidal, C. V. and Muñoz, A. I. (2009). Effect of thermal treatment and applied potential on the electrochemical behaviour of CoCrMo biomedical alloy. Electrochim. Acta, 54(6), pp. 1798-1809. DOI: 10.1016/j.electacta.2008.10.018.

[29] Metikoš-Huković, M., Pilić, Z., Babić, R. and Omanović, D. (2006). Influence of alloying elements on the corrosion stability of CoCrMo implant alloy in Hank's solution. Acta Biomater, 2(6), pp. 693-700. DOI: 10.1016/j.actbio.2006.06.002.

[30] Liu, C., Zhou, Z. and Li, K. Y. (2017). Improved corrosion resistance of CoCrMo alloy with self-passivation ability facilitated by carbon ion implantation. Electrochim. Acta, 241, pp. 331-340. DOI: 10.1016/j.electacta.2017.04.127. 